\title{
RECENZJE
}

\author{
dr Olga Anchimiuk \\ Uniwersytet w Białymstoku \\ Wydział Filologiczny, Instytut Filologii Wschodniosłowiańskiej \\ tel. (85) 7457450 \\ e-mail: anchimiuk.olga@o2.pl
}

\section{Larisa Fiderkiewicz, Фонетика и интонация русского языка, Практическое пособие для студентов, redaktor naukowy: Łukasz Karpiński, Warszawa 2015, 343 s.}

Новейшие исследования в области фонетики посвящены изучению фонологических систем, сегментных явлений, просодии, орфоэпии, интерференции ${ }^{1}$. Результаты фонетических исследований имеют важное прикладное значение в различных областях, таких как графика и орфография, обучение правильному произношению при изучении русского языка как неродного, а также для диагностики и исправления недостатков речи (логопедии и сурдопедагогики). Появляются новые пособия по изучению русской фонетики, в которых реализуется функциональный подход к фонетическим явлениям ${ }^{2}$. Именно обучению правильному произношению при изучении языка как неродного посвящен учебник Larisy Fiderkiewicz „Фонетика и интонация русского языка”. Этот учебник, как сообщается в аннотации, предназначен для студентов-филологов, изучающих русский язык в высших учебных заведениях Польши. В данном пособии отражен

1 „Проблемы фонетики” 2007, вып. 5.

2 Г.Н. Гиржева, Фонетика русского языка, Великий Новгород 2013. 
многолетний опыт работы автора с польской аудиторией в области фонетики, фонологии и интонации.

Нужно заметить, что курс фонетики для студентов-поляков является начальным при освоении русского языка и недостаточность фонетических умений и навыков приводит к коммуникативным неудачам. Поэтому выпускники чаще склонны искать работу, связанную с переводами письменных текстов, работу, не предполагающую применение навыков устной речи. Рассматриваемый учебник предоставляет возможность выработать необходимые произносительные и интонационные навыки.

Объем учебника достаточно большой - 343 страницы. Он разделен на две части: „Часть первая - Звуки”, „Часть вторая - Русская интонация”, в конце учебника на одной странице даны „Образцы транскрипции”. Важным элеменом учебника является „Библиография”, в которой содержатся как класические учебники, так новые.

В „Общих сведениях", в начале пособия автор дает подробное описание речевого аппарата, приводит русский алфавит и фонетическую транскрипцию звуков русского языка. Там же дается краткая характеристика систем гласных и согласных звуков. Краткий теоретический курс делает этот учебник автономным и удобным в использовании.

„Часть первая - Звуки” знакомит студентов с гласными и согласными звуками. Гласные звуки рассматриваются под ударением и в безударной позиции. Большое количество упражнений на каждое правило, построенных по принципу „от простого к сложному”, позволяет овладеть правильным произношением гласных звуков русского языка. Часть упражнений может быть использована для повторения материала и самостоятельной работы.

Наиболее сложной и разнообразной области русской фонетики системе согласных звуков, их произношению и сочетаниям - посвящена большая часть пособия (стр. 52-250). Очень важно для такого учебника, что каждый звук автор рассматривает с учетом особенностей фонетической системы родного (польского) языка. Перед каждым параграфом даются необходимые пояснения того, как произносится звук в русском языке и как его артикуляция соотносится с соотносимым звуком в польском.

Во всех частях учебника последовательно соблюдены принципы дидактики ${ }^{3}$. Материал на отработку правильного произношения построен от

3 Общедидактические принципы обучения (наглядность, сознательность, доступность, посильность) в методике получили обоснование и разработку специальные методические принципы (коммуникативность, устная основа обучения, опора на родной язык учащихся, 
слогов к словам (в препозиции и в постпозиции к слогообразующему гласному), и далее - к словосочетаниям и предложениям.

Отдельно следует отстановиться на материале, который автор включила в упражнения. Для закрепления каждого звука автор использует стихотворения классиков русской литературы: А.С. Пушкина, С. Есенина, М. Цветаевой, В. Маяковского, О. Мандельштама и др., а также большое количество пословиц и поговорок. Кроме стандартных для такого рода учебников слов и словосочетаний на закрепление произношения и ударения, автор использует стихотворные тексты самых разных поэтических направлений. В стихотворениях реализуются разные стихотворные размеры, что дает возможность ознакомить обучаемых с силлабо-тонической системой. Последнее имеет отношение к выявлению правильного ударения и закреплению произношения. Если знать размер, которым написано стихотворение, то эти сведения легко применить для постановки правильного ударения в используемых словоформах. Размещенные в учебнике иллюстрации позволяют студенту на начальном этапе обучения начать знакомство с культурой и литературой России.

Существенной проблемой для учебной литературы по русскому языку для польских студентов является оформление ударения. В рассматриваемом учебнике знак ударения поставлен далеко не во всех упражнениях. Учащийся обнаружит их только в той части тренировочных упражнений, когда звук отрабатывается на уровне словоформы. В большинстве же упражнений, где обычно используются высказывания, знака ударения нет. В большинстве случаев в такого рода упражнениях стоит значок, показывающий, что упражнению сопутствует наличие записи. Наличие звукового сопровождения существенно улучшает использование учебника, так как позволяет, с одной стороны, контролировать произношение преподавателем (в зависимости от подготовленности аудитории), а с другой - давать задание к самостоятельной постановке ударения учащимся. Кроме того, наличие записи позволяет осуществлять самостоятельное обучение.

Часть вторая учебника посвящена русской интонации. Как известно, интонация является весьма сложным средством фонетической организации речи. Описание и освоение интонационных конструкций представляет известную трудность как для носителя русского как родного, так и для студентов-поляков, изучающих русский как неродной. Кроме основательного теоретического описания особенностей интонационных конструкций,

взаимосвязанное обучение видам речевой деятельности и др.), zob. А.Н. Щукин, Обучение иностранным языкам. Теория и практика, Москва 2006, s. 22. 
учебник содержит отличные примеры, в которых графически обозначены особенности интонирования фразы. Примерами являются фразы, которые студенты могут использовать в повседневной речи, тем самым улучшая коммуникативные умения. Параграфы, подробно описывающие основные интонационные конструкции русского языка, начинаются с характеристики ударения, поскольку интонация тесно связана с ударением. Отлично подобранный материал упражнений по интонации, позволяющий закрепить интонационные конструкции так же предоставляет возможность прочесть высказывание с разной интонацией, что существенно способствует уяснению характера русской интонации.

Таким образом, рассматриваемое пособие является полезным средством обучения студентов-поляков русской фонетике и интонации и может оказать помощь учителям школ, которые преподают русский язык.

\section{Литература}

Гиржева Г. Н., Фонетика русского языка, Великий Новгород 2013.

„Проблемы фонетики” 2007, вып. 5.

Щукин А.Н., Обучение иностранным языкам. Теория и практика, Москва 2006. 